\title{
HIGH INFLATION, PRICE STABILITY AND HYSTERESIS EFFECT: EVIDENCE FROM ARGENTINA
}

\section{ALTA INFLACION, ESTABILIDAD DE PRECIOS E HISTERESIS: EVIDENCIA EN ARGENTINA}

\section{CARLOS DABUS*}

Universidad Nacional del Sur - CONICET

\section{FERNANDO DELBIANCO**}

Universidad Nacional del Sur - CONICET

\section{ANDRES FIORITI***}

University of Warwick

\begin{abstract}
We estimate a Currency Substitution model for 1980-2013 periods in Argentina. Following the Mongardini and Mueller (2000) specification, our paper studies the persistence of lower demand of local money, or dollarization, by including a hysteresis variable. By applying an ARDL (Auto Regressive Distributed Lags) model, we found a clear ratchet effect, which implies that in the short run agents do not adjust to changes on the fundamentals, leading to a significant hysteresis variable.
\end{abstract}

Keywords: Hysteresis effect, money demand, currency substitution.

JEL Classification: E00, E41, C01.

* Instituto de Investigaciones Económicas y Sociales del Sur (IIES), Departamento de Economía, Universidad Nacional del Sur (UNS) - Consejo Nacional de Investigaciones Científicas y Técnicas (CONICET), San Andrés 800, Altos de Palihue, 8000 Bahía Blanca, Argentina. Email: cdabus@ criba. edu.ar

** Instituto de Investigaciones Económicas y Sociales del Sur (IIES), Departamento de Economía, Universidad Nacional del Sur (UNS) - Consejo Nacional de Investigaciones Científicas y Técnicas (CONICET), San Andrés 800, Altos de Palihue, 8000 Bahía Blanca, Argentina. Email: fernando. delbianco@uns.edu.ar

*** Department of Economics, University of Warwick, Coventry, CV4 7AL UK. Email: a.fioriti@warwick. ac.uk 


\title{
Resumen
}

\begin{abstract}
En el presente trabajo estimamos un modelo de sustitución de moneda para Argentina en el período 1980-2013. Siguiendo la especificación de Morgandini y Mueller (2000) estudiamos la baja demanda de moneda local, o dolarización, incluyendo una variable de histéresis. Utilizando un modelo ARRD (Auto Regresivo de Rezagos Distribuidos) encontramos un claro efecto Ratchet, lo que implica que en el corto plazo los agentes no ajustan a cambios en los fundamentales, ocasionando que la variable de histéresis sea significativa.
\end{abstract}

Palabras clave: Histéresis, demanda de dinero, sustitución de moneda.

Clasificación JEL: E00, E41, C01.

\section{INTRODUCTION}

The relationship between macroeconomic instability and money demand has been central in the macroeconomics literature. In relation to price instability, over the past decades Latin America experienced periods which went from moderate to high inflation and even hyperinflations (Dabús et al. (2009)), and in most cases these episodes were nearly associated to fast devaluations. In turn, developing countries in general have exhibited lower monetization coefficients than countries of higher levels of per-capita GDP (Mc Loughlin and Kinoshita (2012)). Moreover, lower monetization is associated with lower local currency demand, which in turn represents persistent currency substitution (CS) for foreign money. In the literature this persistence is known as a phenomenon of hysteresis effect, and in some empirical contributions this is approximated by a "ratchet variable" (see for example Mongardini and Mueller (2000), and Valev (2010)). In countries that experienced high inflation periods the CS remained at high levels, even though such episodes were followed by a successful disinflation process. In other words, a lower degree of local currency demand set in. Indeed, Kamin and Ericsson (2003) find a persistent dollarization in Argentina, even after the rapid disinflation that followed the hyperinflations of the end of the ' 80 .

Currency substitution has been vastly studied for many regions and countries. Sharma et al. (2005) find that the domestic currency and the U.S. dollar are substitutes in six Asian countries. In particular, they found that the demand for dollars relative to the domestic currency is due to a change in the opportunity cost of holding domestic money, i.e. exchange rate depreciation, in relation to the opportunity cost of holding dollar, which is given by the domestic interest rate. This result may be an intuitive explanation for the persistence of the dollarization or the Ratchet effect. Also for Asian countries Tavlas (1996) studies the case of Japan and shows that the degree of economic integration and relative inflation performance are key factors to generate currency substitution. In turn, Arize (1991) provides evidence of a negative and 
significant substitution effect on the demand for money during the period of financial deregulation in Korea. Meanwhile, looking to western developed countries, Miles $(1978,1981)$ states the existence of CS in the United States, Canada, and Germany.

On the other hand, a particular issue is the CS behavior in an inflationary environment. According to Kamin and Ericsson (2003, p. 185), the "heavy usage of foreign currency generally has occurred in countries with high and variable inflation rates and where the rate of currency depreciation has been high and variable as well." Moreover, they state that in this kind of economies the opportunity cost of holding domestic currency is often high and uncertain, which induce residents to use foreign currency. High inflation experiences were common in developing countries during the past decades. Latin America was particularly affected by this issue. Despite nowadays most of the countries of this region have controlled their inflationary process, and they have converged to world inflation rates, in the past decades they have been seriously affected by periods of extreme price instability (Dabús (1994), Johnson (2002), Capristán and Ramos Francia (2009)). As a matter of fact, during the '70s and along the '80s several countries of the region experienced episodes of very high and hyperinflation.

The dollarization process increased in times of high inflation as foreign currencies, usually the dollar, substituted the domestic currency ${ }^{1}$. Meanwhile, in several cases the demand for local money did not recovered to previous levels after a stabilization plan, i.e. when disinflation was achieved; instead, a Histeresis effect could be verified, because foreign currency remained in use in the financial system and in transactions (Valev (2010)). In this sense, numerous studies on currency substitution in Latin American countries show that there is a significant degree of dollarization, i.e., the U.S. dollar and domestic currencies are jointly used. For example, Ramirez-Rojas (1985) find the existence of CS in Argentina, Mexico and Uruguay, while Calvo and Vegh (1992) also observed CS in Bolivia, Mexico, Peru, and Uruguay. Nonetheless, Prock et al. (2003) observe that currency substitution occurs especially in Argentina and Brazil, but Mexico exhibits a lower degree of CS. Similarly, Feige et al. (2003) generates estimates of dollarization for Latin American countries and finds evidence in favor of hysteresis effect: a period of financial instability raises the level of dollarization for a long period after the episode of instability has ended. Also Clements and Schwartz (1993) and Reding and Morales (2004) find this effect for Bolivia, where currency substitution increases rapidly in unstable macroeconomic environments, but this is difficult to reverse even after many years of stability. In particular, dollarization levels in Bolivia remained high even after the stabilization of the hyperinflation periods. In this sense, Kamin and Ericsson (2003) find a Histeresis effect due to inflation by means of a cointegration analysis of local money demand in Argentina. In fact, this supports the idea of a reduction in the Argentinean peso demand, attributable to a Histeresis effect, which implies that, even though a successful disinflation policy was carried out after the hyperinflations, there was a persistence of a dollarization process.

1 See for example Ramirez-Rojas (1985), Melvin (1988); Rojas-Suarez (1992) and Clements and Schwartz (1993), who have documented a positive association between exchange rate devaluations and dollarization, in particular in Latin America. 
To sum up, CS seems to be a common feature that arises as a consequence of periods of high instability, more specifically after processes of high inflation and important devaluations of the currency. Regarding this results Latin America, and Argentina as a specific country, appear as cases of special interest. In fact, Argentina suffered two episodes of hyperinflation between 1989 and 1990 followed by long periods of stability and a new episode of rising inflation during the '2000, during the devaluation that followed the crisis of 2002. Therefore, during the whole inflationary process that the region experienced during the past decades there seems to be a persistent dollarization even after inflation was under control.

In short, there is wide evidence that supports the CS as well as the hysteresis effect as consequence of inflationary experiences in unstable macroeconomic environments. This substitution for foreign currency should reduce the margin for monetary policy to the policymakers, so that this can be ineffective if agents react by shifting away from local currency into its substitutes (Sharma et al. (2005)). Thus, this issue seems to deserve more research. In this sense, the goal of this paper is to determine the role of the hysteresis effect in Argentina during the 1980-2013 periods. This is a country with long lasting high inflation and fast devaluations history during this particular period. In fact, Argentina could be an excellent case to analyze the CS process after the episodes of high price instability during the last decades.

The idea is that this study allows to reach a more comprehensive evaluation of the relation between economic instability and currency substitution during periods of high price instability, in particular in episodes in which the economy have suffered of high inflation, recurrent devaluations and fast currency substitution in favor of foreign money. The hypothesis is that big devaluations, which in general are associated with periods of high inflation, left irreversibility on the preference for foreign assets, in particular the US dollar. The idea is to explore the behavior of currency demand in Argentina during the high instability decade of the " 80 s, the price stability period of the '90s associated with the fixed exchange rate and the period of devaluations and relative stability of the '2000. The paper seeks to determine if hysteresis on the demand for local currency took place along these periods.

As usual, CS is approximated by the ratio of local currency in relation to foreign currency, which also considers deposits in both currencies, while the persistence of CS is represented by a hysteresis variable. Our results show the presence of a hysteresis effect after the long period of price stability observed during the convertibility period as well as a deep fall on the currency demand after the devaluation of 2002.

The paper is structured as follows. Section 2 describes the data and methodology. Section 3 presents the empirical results, and finally Section 4 concludes.

\section{DATA AND VARIABLES}

\section{II.1. Data}

The sources of the data are the Central Bank of Argentina (BCRA), the World Bank and the IMF. The variables used for this work are deposits in local currency, 
deposits in foreign currency, cash holdings in local currency, cash holdings in foreign currency, inter-annual interest rate variation and exchange rate.

As it can be seen in Figure 1, during the period under study Argentina experienced high inflation during the ' 80 s with a mild control from the Austral plan. By the end of the ' 80 s high inflation reappeared, mostly between 1987 and 1988, leading to hyperinflations from April to July of 1989 and in the beginnings of 1990. These events were followed by a short period of stable but high inflation that ended the beginning of 1991 with new episodes of increasing inflation rate.

In order to control the inflationary process the government implemented a convertibility program, fixing the exchange rate between the Argentinean peso and the US dollar at a rate of 1 to 1 . This policy leaded to a long period of price stability that ended with the cancellation of the program in January 2002. At that time the economy suffered a strong devaluation and new episodes of inflation that were controlled during the 2003-2007 period. From 2007 onwards price rose steadily year by year at an average annual rate higher than $20 \%$, which forced to periodical exchange rate devaluations. Hence, the Argentinean economy suffered different periods of inflation, ranging from moderate to hyperinflations. In turn, on the side of the exchange rate the country experienced several devaluations, which in general were associated with increases on inflation.

In Figure 2 we can observe peaks of high currency substitution ratios in two particular periods. Not surprisingly, the first was during the hyper inflationary process

FIGURE 1

ARGENTINEAN ANNUAL INFLATION RATE

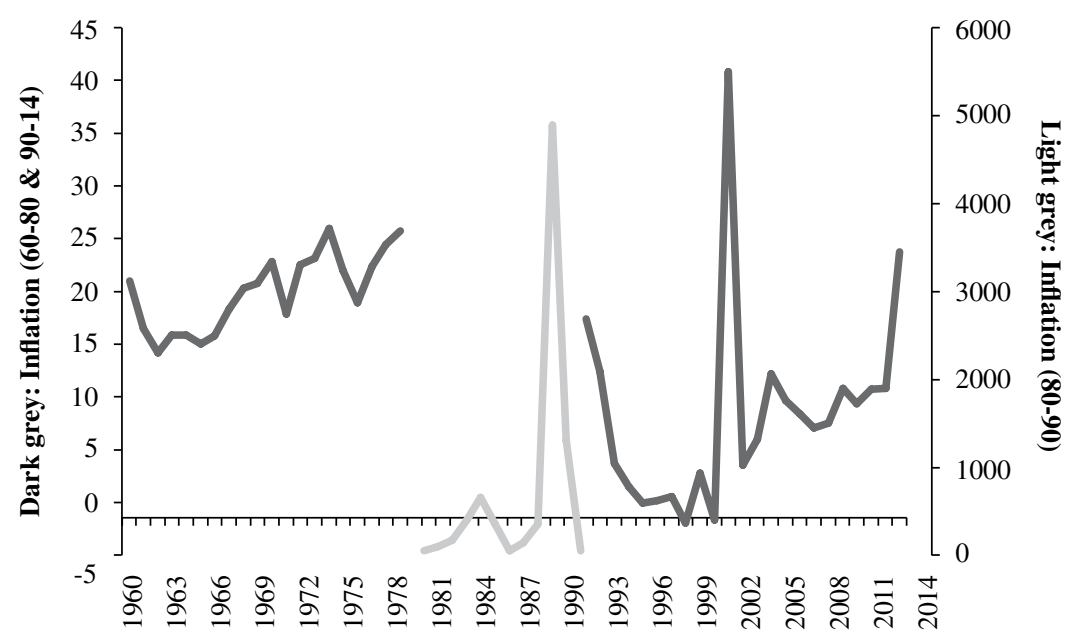

Source: IMF. 


\section{FIGURE 2}

\section{CURRENCY SUBSTITUTION RATIOS}

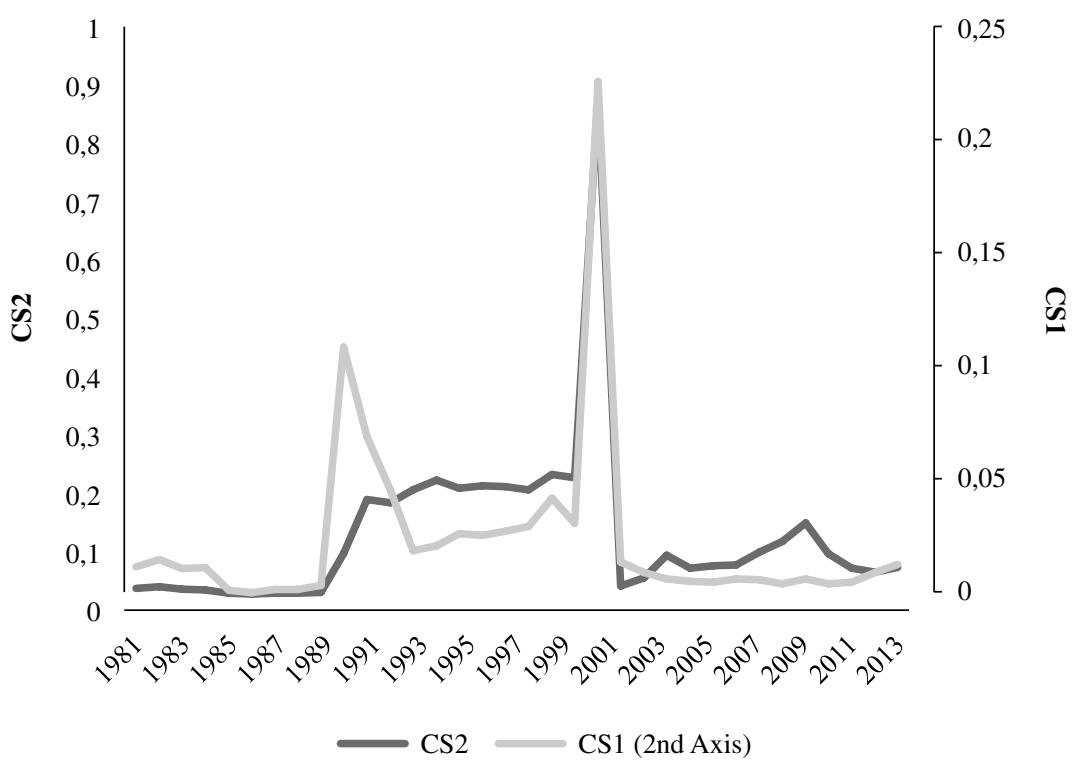

Source: Author's elaboration based on BCRA data.

in the late 80s, while the second case, which was the highest CS ratio along all the period under study, occurred during 2001 and 2002. This episode is associated with the end of the convertibility plan and the subsequent devaluation, as well as the brief inflationary process related with this.

\section{II.2. Econometric Model}

We work with two CS coefficients: CS1, which is based on deposits (deposits in dollars over overall deposits), and CS2, that includes cash. The hysteresis variables are the maximum values reached by the CS ratios. Thus, they represent the historical pikes of the ratio. We work in base to the following structural model to explain the Currency Substitution ratios:

$$
C S i_{t}=\alpha+\beta_{1} C S i_{t-1-L}+\beta_{2} \Delta I N T_{t-L}+\beta_{3} E R_{t-L}+\beta_{4} R A T_{t-L}+\mu_{t}
$$

The main difference between our paper and Mongardini and Mueller (2000) is that we include as explicative the difference in the deposit interest rate, instead of the 
difference between US treasury bills and the sovereign bonds. This is because of the lack of a long and homogenous series of bonds to contrast with those AAA from USA ${ }^{2}$.

The transformation of the CS ratios that Mongardini and Mueller (2000) suggest is:

$$
L C S i_{t}=\log \left(\frac{1-C S i_{t}}{C S i_{t}}\right)
$$

However, we use CSi as the dependent variable because when we consider this transformation the results are not trustable due to autocorrelation problems (see Table 5 in the Appendix). This will be explained in more detail in Section 3.

\section{II.3. Methodology}

Equation (1) will be estimated by means of an ARDL (Auto Regressive Distributed Lags) model $^{3}$. We chose this specification in order to estimate the short and long run coefficients. A valid alternative will be to estimate a VEC model, but as we have in mind only one dependent variable the ARDL procedure is preferred.

Table 3 in the Appendix shows the Augmented Dickey-Fuller, the Phillips-Perron and the Zivot-Andrews unit root tests for the series under analysis. The results of these tests indicate that a cointegration analysis is inappropriate due to different integration levels within the variables.

The first step in the ARDL procedure by Pesaran and Smith (1995) is to test for the long-run significance of the explanatory variables. In the case of equation (1), it involves the testing of the joint long-run significance of the constant, the interest rate, the exchange rate, and the ratchet variables. The tests are distributed according to a nonstandard F-statistic, which has different critical values depending on whether the dependent variable is stationary or nonstationary. Pesaran et al. (2001) presents the tables with the F-critical values.

We then proceed to estimate equation (1). We use two ways to represent the CS ratios, in differences and in the logarithmic transformation proposed by Mongardini and Mueller (2000). We also estimate with different lags (and present the Information Criteria of each regression). The estimation procedure uses the ARDL package for Stata, with the option of expressing the regression as an error correction form, i.e. with the differenced variables. Tables 1 and 2 in the next section present the regression results.

2 We also used other specifications in order to fill the gap between local and foreign interest rates by including the EMBI index or the US TB10y. Nonetheless, both variables were removed from the specification because they were not significant and provoke collinearity problems. These estimations are available upon request.

3 Pesaran and Smith (1995), Pesaran et al. (2001), and Mongardini and Mueller (2000). 


\section{EMPIRICAL EVIDENCE}

First, we can observe the unit root tests shown in Table 3 in the Appendix. The ADF concludes that the series are I(1) in all cases. The results displayed are with a specification of two lags but they are robust to other quantity of lags (e.g. 1 or 4 lags).

In light of these results, we estimate equation (1) as a differenced model, with the distributed lags acting like an error correction model. Tables 1 and 2 contain the short and the long run coefficients of the model with the best information criteria ${ }^{4}$. It is crucial the absence of serial correlation in the model, which is confirmed by the alternative Durwin-Watson test.

The F-tests for joint significance are made against the critical values given in Pesaran et al. (2001). The critical values depend on the $k+1$ variables specified in the model and whether the series are $\mathrm{I}(0)$ or $\mathrm{I}(1)$.

When we performed the bound tests, the F-statistics found were always significant when the ratchet variables were included in the model. When they are not, the rejection of the null hypothesis of non-joint significance depends on the dependent variable explained in the regression. For the equation when CS1 is the dependent variable, we found an F-statistic of 68.74, which is higher than the bounds from Pesaran et al. (2001). Also, for the specification of CS2 the F-statistic is 9.06 and the bounds are also below that value (for the $\mathrm{k}$ used and even at a significance of 1\%).

Tables 1 and 2 show the relation between the explanatory variables. In general they present the expected signs. In first place, regarding the short run effects the dependent variable lagged one period is significant and with negative sign in most cases, which implies that a higher CS is followed by a lower increase of this coefficient in the next periods. Thus, currency substitution seems to show a convergent trend during the period considered. Interest rate, in current and lagged values, as expected, affects negatively CS when significant, i.e. a higher interest rate leads to higher local currency demand, thus lower substitution. In turn, the lagged exchange rate is also significant, which is intuitively acceptable: higher devaluation of local currency leads to a future currency demand reduction and then higher currency substitution. Finally, the results show that the ratchet effect is significant and with the expected sign in all cases. In current values this affects positively CS coefficients, i.e. a higher persistence of preference for foreign currency implies higher currency substitution.

On the other hand, also the long run regressions show the expected results. CS1 coefficient is affected negatively by the interest rate, positively by the exchange rate and the ratchet effect. Moreover, similarly to Mongardini and Mueller (2000), there is no long run effect in the case of the wider version of currency substitution, i.e. CS2, which includes cash.

Our results show that there is evidence of a long run relationship in both of the ratios estimated. The difference is that when we include cash the relationship seems weaker.

4 We used the ARDL command of Stata to obtain this model. This command automatically chooses the best model based on information criteria. Tables 4 and 5 in the Appendix exhibit additional estimations. 
TABLE 1

CURRENCY SUBSTITUTION (CS1) ESTIMATION RESULTS

\begin{tabular}{|c|c|c|c|}
\hline VARIABLES & ADJ & LONG RUN & SHORT RUN \\
\hline D. (deposit interest rate) & & \multirow{19}{*}{$\begin{array}{c}-0.000141 \\
(8.89 \mathrm{E}-05) \\
0.331^{* *} \\
(0.129) \\
-1.209^{* *} \\
(0.459)\end{array}$} & $1.57 \mathrm{E}-07$ \\
\hline LD. (deposit interest rate) & & & $\begin{array}{c}(8.56 \mathrm{E}-07) \\
-1.23 \mathrm{E}-05 * * * \\
(215 \mathrm{E}-06)\end{array}$ \\
\hline L2D. (deposit interest rate) & & & $-1.80 \mathrm{E}-05^{* * *}$ \\
\hline L3D. (deposit interest rate) & & & $\begin{array}{l}(1.88 \mathrm{E}-06) \\
-3.16 \mathrm{E}-06 * * \\
(125 \mathrm{E}-06)\end{array}$ \\
\hline D. (exchange rate) & & & $\begin{array}{c}0.0344 \\
(0.0256)\end{array}$ \\
\hline LD.(exchange rate) & & & $\begin{array}{c}0.0711^{*} \\
(0.039)\end{array}$ \\
\hline L2D.(exchange rate) & & & $\begin{array}{c}-0.0656^{* *} \\
(0.0257)\end{array}$ \\
\hline L3D.(exchange rate) & & & $\begin{array}{c}-0.0222 * * \\
(0.00825)\end{array}$ \\
\hline D.ratchet1 & & & $\begin{array}{l}1.001 * * * \\
(0.0214)\end{array}$ \\
\hline LD.ratchet1 & & & $\begin{array}{c}-1.662 * * * \\
(0.19)\end{array}$ \\
\hline L2D.ratchet1 & & & $\begin{array}{l}-0.189 \\
(0.109)\end{array}$ \\
\hline L3D.ratchet1 & & & $\begin{array}{l}0.268 * * * \\
(0.0693)\end{array}$ \\
\hline L. (deposit interest rate) & & & \\
\hline L. (exchange rate) & & & \\
\hline L.ratchet1 & & & \\
\hline L.cs1 & $\begin{array}{c}0.111 \\
(0.0653)\end{array}$ & & \\
\hline Constant & & & $\begin{array}{l}-0.00813 \\
(0.00712)\end{array}$ \\
\hline Observations & 29 & & \\
\hline R-squared & 0.998 & & \\
\hline
\end{tabular}

Standard errors in parentheses.

$* * * \mathrm{p}<0.01, * * \mathrm{p}<0.05, * \mathrm{p}<0.1$.

L: lagged; D: difference; LD: lagged difference, L2D: second lagged difference.

L: lagged; D: difference; LD: lagged difference, L2D: second lagged difference. 
TABLE 2

CURRENCY SUBSTITUTION (CS2) ESTIMATION RESULTS

\begin{tabular}{|c|c|c|c|}
\hline VARIABLES & ADJ & LR & SR \\
\hline LD.cs2 & & & $\begin{array}{l}-0.265 \\
(0.202)\end{array}$ \\
\hline D. (deposit interest rate) & & & $\begin{array}{c}3.39 \mathrm{E}-07 \\
(3.61 \mathrm{E}-07)\end{array}$ \\
\hline LD.(deposit interest rate) & & & $\begin{array}{c}-6.79 \mathrm{E}-06 * * * \\
(1.14 \mathrm{E}-06)\end{array}$ \\
\hline L2D.(deposit interest rate) & & & $\begin{array}{c}1.11 \mathrm{E}-06 \\
(1.41 \mathrm{E}-06)\end{array}$ \\
\hline L3D.(deposit interest rate) & & & $\begin{array}{c}2.19 \mathrm{E}-06 * * * \\
(6.41 \mathrm{E}-07)\end{array}$ \\
\hline D. (exchange rate) & & & $\begin{array}{l}0.00565 \\
(0.0089)\end{array}$ \\
\hline LD.(exchange rate) & & & $\begin{array}{c}0.0151 \\
(0.0122)\end{array}$ \\
\hline D.ratchet2 & & & $\begin{array}{l}1.631 * * * * \\
(0.0543)\end{array}$ \\
\hline LD.ratchet2 & & & $\begin{array}{c}-1.649 * * * \\
(0.346)\end{array}$ \\
\hline L2D.ratchet2 & & & $\begin{array}{c}-0.765^{*} \\
(0.415)\end{array}$ \\
\hline L.(deposit interest rate) & & $\begin{array}{c}-6.95 \mathrm{E}-05 \\
(0.00018)\end{array}$ & \\
\hline L.(exchange rate) & & $\begin{array}{l}0.0929 \\
(0.314)\end{array}$ & \\
\hline L.ratchet2 & & $\begin{array}{l}-1.458 \\
(4.788)\end{array}$ & \\
\hline L.cs2 & $\begin{array}{c}0.056 \\
(0.148)\end{array}$ & & \\
\hline Constant & & & $\begin{array}{l}-0.00453 \\
(0.00355)\end{array}$ \\
\hline Observations & 29 & & \\
\hline R-squared & 0.996 & & \\
\hline
\end{tabular}

Standard errors in parentheses.

$* * * \mathrm{p}<0.01, * * \mathrm{p}<0.05, * \mathrm{p}<0.1$.

Note: L: lagged; D: difference; LD: lagged difference, L2D: second lagged difference.

\section{CONCLUSIONS}

Our paper has considered episodes of high inflation and price stability in Argentina that span along the 1980-2013 period. During this period exchange rates and interest rates fluctuated frequently, leading to changes in the portfolio of Argentinean residents between local and foreign currency.

One important question that needs to be answered is whether agents adjust their currency portfolio after observing changes in the fundamentals or not. On this regard, it can be thought that agents do not adjust immediately because they expect more 
changes on the short run, while in the long run the hypothesis of adjustment should take place.

We test this idea by using a Ratchet effect variable. This specification of the currency substitution allow us to explain the demand for local currency that agents have as a function of the interest rate, the exchange rate and some sort of past events, like previous peaks of CS associated with increasing inflation and fast devaluations (this is the idea behind the Ratchet variable).

For the Argentinean case, by means of an ARDL estimation, we show that in the short run agents do not adjust to changes on the fundamentals, leading to a significant Ratchet effect. Our results show that agents prefer to keep high holdings of foreign currency even when the interest is higher than before and wait for the new conditions to hold for a period before changing their portfolio in favor of local currency. In turn, the second important implication of our paper is that in the long run only the fundamentals matter; in fact, we found that in the long run agents adjust their portfolio in favor of local currency.

Our paper contributes to the idea that countries that experienced high inflation periods have trouble to reposition their currency since agents hold a safer currency in order to avoid future loses of the purchasing power of their savings. In order to prevent this pattern of behavior, countries should commit to long periods of price stability. This recommendation goes in line with the consensus that central banks should focus on inflation targeting as their main policy if they want to have control over the money demand by influencing the interest rate.

Further work can consists in expand the sample to other countries with a history of price instability. This could allow determining if it is possible to generalize those episodes of high inflation and fast devaluations influence in the composition of the agents' portfolio, as well as in their preferences for local currency.

\section{BIBLIOGRAPHY}

ARIZE, C.A. (1991). "Currency substitution in Korea”, The American Economist 35 (2), pp. 67-72.

CALVO, G.A. and C.A. VEGH (1992). "Currency substitution in developing countries: An introduction", Revista de Análisis Económico 7, pp. 3-27.

CAPRISTAN, C. and M. RAMOS FRANCIA (2009). "Inflation Dynamics in Latin America", Contemporary Economic Policy 27 (3), pp. 349-362.

CLEMENTS, B. and G. SCHWARTZ (1993). "Currency Substitution: the Recent experience of Bolivia", World Development 21 (11), pp. 1883-1893.

DABUS, C. (1994). "Inflación, Precios Relativos y Cambio Estructural: Argentina 1960-1990”, Estudios de Economía 21 (1), pp. 47-64.

DABUS, C., M. CARABALLO and D. CARAMUTA (2009). "Price Behaviour at High Inflation: Evidence from Latin America", in Inflation: Causes and Effects, Control and Prediction, Nova Science Publishers, Leon V. Schwartz (editor), Nueva York.

FEIGE, E., M. FAULEND, V. ŠONJE and V. ŠOŠIÆ (2003). "Unofficial Dollarization in Latin America: Currency Substitution, Network Externalities and Irreversibility", in The Dollarization Debate, J. Dean, D. Salvatore, T. Willett (Eds.), Oxford University Press.

JOHNSON, C. (2002). "Inflation Uncertainty in Chile: Asymmetries and the News Impact Curve", Revista de Análisis Económico 17 (1), pp. 3-20.

KAMIN, S.B. and N.R. ERICSSON (2003). "Dollarization in post-hyperinflationary Argentina", Journal of International Money and Finance 22, pp. 185-211. 
Mc LOUGHLIN, C. and N. KINOSHITA (2012). "Monetization in Low- and Middle-Income Countries", IMF Working Paper 12/160.

MELVIN, M. (1988). "The dollarization of Latin America as a market-enforced monetary reform: Evidence and implications", Economic Development and Cultural Change 36 (3), pp. 543-558.

MILES, M.A. (1978). "Currency substitution, flexible exchange rates and monetary independence", American Economic Review 68, pp. 428-436.

MILES, M.A. (1981). "Currency substitution: Some further results and conclusions", Southern Economic Journal 43 (8), pp. 78-86.

MONGARDINI, J. and J. MUELLER (2000). "Ratchet Effects in Currency Substitution: An Application to the Kyrgyz Republic", IMF Staff Papers 47 (2).

PESARAN, M.H. and R. SMITH (1995). "Estimating long-run relationships from dynamic heterogeneous panels", Journal of Econometrics 68 (1), pp. 79-113.

PESARAN, M.H., Y. SHIN and R. SMITH (2001). "Bounds testing approaches to the analysis of level relationships", Journal of Applied Econometrics 16, pp. 289-326.

PROCK, J., G.A. SOYDEMIR and B.A. ABUGRI (2003). "Currency substitution: Evidence from Latin America", Journal of Policy Modeling 25, pp. 415-430.

RAMIREZ-ROJAS, C. (1985). "Currency Substitution in Argentina, Mexico, and Uruguay", IMF Staff Papers 32 (4), pp. 629-667.

ROJAS-SUAREZ, L. (1992). "Currency substitution and inflation in Peru”, Revista de Análisis Económico 7 (1), pp. 153-176.

REDING, P. and J.A. MORALES (2004). "Currency Substitution and Network Externalities", SSRN Working Paper Series 549061.

SHARMA, S., M. KANDIL and S. CHAISRISAWATSUK (2005). "Currency substitution in Asian countries", Journal of Asian Economics 16, pp. 489-532.

TAVLAS, G.S. (1996). "Currency substitution and the international demand for yen", in The macroeconomics of international currencies: Theory, policy and evidence, P. Mizen, \& E. J. Pentecost (Eds.), Vermont: Edward Elgar, pp. 178-192.

VALEV, N.T. (2010). "The hysteresis of currency substitution: Currency risk vs. network externalities", Journal of International Money and Finance 29 (2), pp. 224-235. 


\section{APPENDIX}

TABLE 3

UNIT ROOT TESTS RESULTS

\begin{tabular}{|c|c|c|c|c|}
\hline Variable & & $\mathrm{ADF}$ & PPERRON & $\mathrm{ZA}$ \\
\hline cs1 & $\begin{array}{l}\text { level } \\
\text { difference }\end{array}$ & $\begin{array}{c}-2.274 \\
-4.717 * * *\end{array}$ & $-4.42 * * *$ & -7.91 *** \\
\hline $\operatorname{cs} 2$ & $\begin{array}{l}\text { level } \\
\text { difference }\end{array}$ & $\begin{array}{c}-2.848^{*} \\
-5.124 * * *\end{array}$ & $-4.78 * * *$ & $-6.14 * * *$ \\
\hline Lcs 1 & $\begin{array}{l}\text { level } \\
\text { difference }\end{array}$ & $\begin{array}{c}-1.676 \\
-3.123^{*} *\end{array}$ & $\begin{array}{c}-2.152 \\
-7.177 * * *\end{array}$ & $-5.440^{* *}$ \\
\hline Lcs2 & $\begin{array}{l}\text { level } \\
\text { difference }\end{array}$ & $\begin{array}{c}-2.392 \\
-4.595^{* * *}\end{array}$ & $\begin{array}{c}-2.584 \\
-6.174 * * *\end{array}$ & $-4.863^{*}$ \\
\hline ratchet 1 & $\begin{array}{l}\text { level } \\
\text { difference }\end{array}$ & $\begin{array}{c}-2.25 \\
-5.672 * * *\end{array}$ & $\begin{array}{c}-0.78 \\
-5.77 * * *\end{array}$ & $-17.59 * * *$ \\
\hline ratchet2 & $\begin{array}{l}\text { level } \\
\text { difference }\end{array}$ & $\begin{array}{c}-2.327 \\
-5.852 * * *\end{array}$ & $\begin{array}{c}-1.016 \\
-5.86 * * *\end{array}$ & $-5.39 * *$ \\
\hline inflation & $\begin{array}{l}\text { level } \\
\text { difference }\end{array}$ & $\begin{array}{c}-2.537 \\
-6.084 * * *\end{array}$ & $\begin{array}{c}-2.7 \\
-6.59 * * *\end{array}$ & $\begin{array}{c}-4.29 \\
-6.86^{* * * *}\end{array}$ \\
\hline Deposit interest rate & $\begin{array}{l}\text { level } \\
\text { difference }\end{array}$ & $\begin{array}{c}-3.264 \\
-5.349 * * *\end{array}$ & $-5.42 * * *$ & $-7.15 * * *$ \\
\hline EMBI & $\begin{array}{l}\text { level } \\
\text { difference }\end{array}$ & $\begin{array}{l}-1.66 \\
-2.171\end{array}$ & $\begin{array}{c}-2.7 \\
-4.274 * * *\end{array}$ & $-5.36 * * *$ \\
\hline Exchange rate & $\begin{array}{l}\text { level } \\
\text { difference }\end{array}$ & $\begin{array}{c}2.272 \\
-3.342 * *\end{array}$ & $\begin{array}{c}2.55 \\
-6.40^{* * *}\end{array}$ & $\begin{array}{c}-4.40 \\
-7.93 * * *\end{array}$ \\
\hline US treasury bills & level & $\begin{array}{c}-0.826 \\
-4.194 * * *\end{array}$ & $\begin{array}{c}-1.196 \\
-8.929 * * *\end{array}$ & $-6.076^{* * *}$ \\
\hline
\end{tabular}

$*$,** and ***: signifative at 10,5 and $1 \%$ respectively Lags selected: 2 .

ADF: Augmented Dickey Fuller test.

PPERRON: Phillips Perron test $(Z(t)$ statistic).

ZANDREWS: Zivot Andrews test. 
TABLE 4

EXTRA CURRENCY SUBSTITUTION ESTIMATION RESULTS

\begin{tabular}{|c|c|c|c|c|c|c|}
\hline \multirow{2}{*}{ Dependent } & 1 & 2 & 3 & 4 & 5 & 6 \\
\hline & d.cs1 & d.cs2 & d.cs1 & d.cs2 & d.cs1 & d.cs 2 \\
\hline Dep. L1 & -0.9323257 & -0.809793 & -0.1845301 & -0.4250911 & -0.3749371 & -0.4818969 \\
\hline Dep. LD & & & -0.031831 & 0.0085045 & 0.2437502 & -0.0236613 \\
\hline & & & $(0.508)$ & $(0.799)$ & $(0.218)$ & $(0.836)$ \\
\hline Dep. L2 & & & & & $\begin{array}{c}-0.0411856 \\
(0.127)\end{array}$ & $\begin{array}{c}-0.0048084 \\
(0.83)\end{array}$ \\
\hline d.INT & -0.0000645 & $6.72 \mathrm{E}-06$ & $-3.29 \mathrm{E}-06$ & -0.0000107 & -0.0000698 & -0.0000198 \\
\hline & $(0.00)^{*}$ & $(0.134)$ & $(0.907)$ & $(0.008) * * *$ & $(0.024)^{* *}$ & $(0.00)^{* * * *}$ \\
\hline d.INT L1 & & & $\begin{array}{c}0.0000255 \\
(0.159)\end{array}$ & $\begin{array}{c}-0.0000113 \\
(0.00) * * *\end{array}$ & $\begin{array}{c}-0.0000562 \\
(0.033) * *\end{array}$ & $\begin{array}{c}-0.0000198 \\
(0.00) * * *\end{array}$ \\
\hline d.INT L2 & & & & & -0.000041 & $-8.34 \mathrm{E}-06$ \\
\hline d.ER & $\begin{array}{l}0.0219445 \\
(0.001)^{* * * *}\end{array}$ & $\begin{array}{c}-0.001490 \\
(0.345)\end{array}$ & $\begin{array}{c}0.0001334 \\
(0.99)\end{array}$ & $\begin{array}{c}0.0028924 \\
(0.033) * *\end{array}$ & $\begin{array}{c}0.0227696 \\
(0.052) *\end{array}$ & 0.0063862 \\
\hline d.ER L1 & & & -0.008775 & 0.001845 & 0.0184722 & 0.0049456 \\
\hline d. ER L2 & & & $(0.19)$ & $(0.026)^{* *}$ & $\begin{array}{c}(0.058)^{*} \\
0.011037 \\
(0.056) *\end{array}$ & $\begin{array}{c}(0.00)^{* * * *} \\
0.0030104 \\
(0.00) * * *\end{array}$ \\
\hline d.RAT & 1.194194 & 1.808319 & 1.04529 & 1.74321 & 1.083278 & 1.754212 \\
\hline & $(0.00)$ & $(0.00)$ & $(0.00)^{* * *}$ & $(0.00)^{* * *}$ & $(0.00)^{* * * *}$ & $(0.00)^{* * *}$ \\
\hline d.RAT L1 & & & $\begin{array}{c}-0.973897 \\
(0.00)^{* * *}\end{array}$ & $\begin{array}{c}-1.009788 \\
(0.00) * * *\end{array}$ & $\begin{array}{c}-1.076623 \\
(0.00)^{* * *}\end{array}$ & $\begin{array}{c}-0.8632007 \\
(0.01)^{* *}\end{array}$ \\
\hline d.RAT L2 & & & & & $\begin{array}{c}0.3591525 \\
(0.137)\end{array}$ & $\begin{array}{c}-0.0255576 \\
(0.906)\end{array}$ \\
\hline Constant & $\begin{array}{c}0.1682541 \\
(0.00)^{* * *}\end{array}$ & $\begin{array}{l}0.0259578 \\
(0.001)^{* * *}\end{array}$ & $\begin{array}{c}0.0425685 \\
(0.309)\end{array}$ & $\begin{array}{l}0.0145112 \\
(0.008)^{* * *}\end{array}$ & $\begin{array}{c}0.0886563 \\
(0.056)^{* *}\end{array}$ & $\begin{array}{c}0.0250768 \\
(0.00) * * *\end{array}$ \\
\hline \multicolumn{7}{|l|}{ Long run relations } \\
\hline INT & $\begin{array}{l}0.0001356 \\
(0.00)^{* * * *}\end{array}$ & $\begin{array}{c}8.69 \mathrm{E}-06 \\
(0.317)\end{array}$ & $\begin{array}{c}0.0001559 \\
(0.17)\end{array}$ & $\begin{array}{c}0.000033 \\
(0.005)^{* * *}\end{array}$ & $\begin{array}{l}0.000198 \\
(0.00)^{* * *}\end{array}$ & $\begin{array}{c}0.0000428 \\
(0.00)^{* * * *}\end{array}$ \\
\hline ER & $\begin{array}{c}-0.0504246 \\
(0.00) * * *\end{array}$ & $\begin{array}{c}-0.004975 \\
(0.104)\end{array}$ & $\begin{array}{c}-0.0544277 \\
(0.153)\end{array}$ & $\begin{array}{l}-0.0100562 \\
(0.007)^{* * *}\end{array}$ & $\begin{array}{c}-0.0689099 \\
(0.00)^{* * *}\end{array}$ & $\begin{array}{c}-0.014542 \\
(0.00)^{* * *}\end{array}$ \\
\hline RAT & $\begin{array}{c}-0.127391 \\
(0.00)^{* * *}\end{array}$ & $\begin{array}{c}-0.106084 \\
(0.042)^{* *}\end{array}$ & $\begin{array}{c}-0.1913081 \\
(0.204)\end{array}$ & $\begin{array}{c}-0.1126139 \\
(0.038)^{* *}\end{array}$ & $\begin{array}{c}-0.1914474 \\
(0.00)^{* * *}\end{array}$ & $\begin{array}{c}-0.1946534 \\
(0.00)^{* * * *}\end{array}$ \\
\hline N. ob & 32 & 32 & 31 & 31 & 30 & 30 \\
\hline R2 adj & 0.95405511 & 0.9568342 & 0.96675172 & 0.98799139 & 0.99114464 & 0.99520325 \\
\hline DWA (Prob > chi2) & 0.8906 & 0.1774 & 0.4861 & 0.0241 & 0.3507 & 0.8829 \\
\hline AIC & -99.1198 & -188.6189 & -133.6555 & -206.8399 & -130.0692 & -205.9422 \\
\hline BIC & -87.6479 & -177.147 & -118.2423 & -191.4267 & -110.9271 & -186.8001 \\
\hline
\end{tabular}

$*, * *$ and $* * *$ : significant at $10 \%, 5 \%$ and $1 \%$ respectively. 
TABLE 5

EXTRA CURRENCY SUBSTITUTION ESTIMATION RESULTS (WITH CS LOG-TRANSFORMED)

\begin{tabular}{|c|c|c|c|c|c|c|}
\hline \multirow{2}{*}{ Depend } & 1 & 2 & 3 & 4 & 5 & 6 \\
\hline & d.Lcs1 & d.Lcs2 & d.Lcs1 & d.Lcs2 & d.Lcs 1 & d.Lcs 2 \\
\hline Dep. L1 & $\begin{array}{c}-0.437652 \\
(0.00)^{* * *}\end{array}$ & $\begin{array}{c}-0.2845489 \\
(0.003) * * *\end{array}$ & $\begin{array}{c}-0.0723144 \\
(0.33)\end{array}$ & $\begin{array}{c}-0.2483602 \\
(0.007) * * * *\end{array}$ & $\begin{array}{c}-0.1835561 \\
(0.017)^{* *}\end{array}$ & $\begin{array}{c}-0.3615988 \\
(0.00)^{* * *}\end{array}$ \\
\hline Dep. LD & & & $\begin{array}{c}-0.1287837 \\
(0.095)^{*}\end{array}$ & $\begin{array}{c}-0.0955479 \\
(0.523)\end{array}$ & $\begin{array}{c}0.230385 \\
(0.2)\end{array}$ & $\begin{array}{c}-0.159452 \\
(0.393)\end{array}$ \\
\hline Dep. L2 & & & & & $\begin{array}{c}-0.0393656 \\
0.476\end{array}$ & $\begin{array}{c}0.0992455 \\
0.333\end{array}$ \\
\hline d.INT & $\begin{array}{l}0.0009102 \\
(0.006) * * *\end{array}$ & $\begin{array}{l}0.0005917 \\
(0.006) * * *\end{array}$ & $\begin{array}{c}0.00092 \\
(0.004) * * *\end{array}$ & $\begin{array}{l}0.0012744 \\
(0.002)^{* * *}\end{array}$ & $\begin{array}{l}0.0013138 \\
(0.001)^{* * * *}\end{array}$ & $\begin{array}{c}0.002017 \\
(0.001)^{* * * *}\end{array}$ \\
\hline d.INT L1 & & & $\begin{array}{c}-0.0002309 \\
(0.187)\end{array}$ & $\begin{array}{c}0.0003183 \\
(0.114)\end{array}$ & $\begin{array}{c}0.0000636 \\
(0.807)\end{array}$ & $\begin{array}{c}0.0006379 \\
(0.15)\end{array}$ \\
\hline d.INT L2 & & & & & $\begin{array}{c}0.0004074 \\
(0.011)^{* *}\end{array}$ & $\begin{array}{c}0.0003454 \\
(0.051)^{*}\end{array}$ \\
\hline d.ER & $\begin{array}{c}-0.247695 \\
(0.041)^{* *}\end{array}$ & $\begin{array}{c}-0.1715483 \\
(0.022)^{* *}\end{array}$ & $\begin{array}{c}-0.2159089 \\
(0.042)^{* *}\end{array}$ & $\begin{array}{c}-0.3597671 \\
(0.006)^{* * *}\end{array}$ & $\begin{array}{r}-0.3815997 \\
(0.002)^{* * *}\end{array}$ & $\begin{array}{r}-0.6340359 \\
(0.001)^{* * * *}\end{array}$ \\
\hline $\begin{array}{l}\text { d.ER L1 } \\
\text { d. ER L2 }\end{array}$ & & & $\begin{array}{l}1.37 \mathrm{E}-01 \\
(0.034)^{* *}\end{array}$ & $\begin{array}{c}-0.0394983 \\
(0.535)\end{array}$ & $\begin{array}{c}0.0217142 \\
(0.797) \\
-0.1432606 \\
(0.017)^{* *}\end{array}$ & $\begin{array}{c}-0.1438447 \\
(0.271) \\
-0.1408646 \\
(0.007) * * *\end{array}$ \\
\hline d.RAT & $\begin{array}{l}-6.52954 \\
(0.00) * * *\end{array}$ & $\begin{array}{c}-23.02295 \\
(0.00) * * *\end{array}$ & $\begin{array}{c}-5.005227 \\
(0.00)^{* * *}\end{array}$ & $\begin{array}{c}-22.12786 \\
(0.00)^{* * * *}\end{array}$ & $\begin{array}{c}-5.318335 \\
(0.00)^{* * * *}\end{array}$ & $\begin{array}{l}-22.6562 \\
(0.00)^{* * * *}\end{array}$ \\
\hline d.RAT L1 & & & $\begin{array}{l}7.698748 \\
(0.00)^{* * *}\end{array}$ & $\begin{array}{c}14.6955 \\
(0.015)^{* *}\end{array}$ & $\begin{array}{l}8.758995 \\
(0.00)^{* * *}\end{array}$ & $\begin{array}{l}11.29802 \\
(0.038)^{* *}\end{array}$ \\
\hline d.RAT L2 & & & & & $\begin{array}{c}-4.142525 \\
(0.011)^{* *}\end{array}$ & $\begin{array}{c}-0.9112178 \\
(0.843)\end{array}$ \\
\hline Constant & $\begin{array}{c}0.6532414 \\
(0.177)\end{array}$ & $\begin{array}{c}0.6478771 \\
(0.221)\end{array}$ & $\begin{array}{c}-0.0090576 \\
(0.969)\end{array}$ & $\begin{array}{c}0.5676046 \\
(0.191)\end{array}$ & $\begin{array}{c}0.1405947 \\
(0.382)\end{array}$ & $\begin{array}{c}0.6480704 \\
(0.046)\end{array}$ \\
\hline \multicolumn{7}{|l|}{ Long run relations } \\
\hline INT & $\begin{array}{l}-0.004415 \\
(0.002)^{* * *}\end{array}$ & $\begin{array}{c}-0.0039655 \\
(0.03)^{* *}\end{array}$ & $\begin{array}{c}-0.0176114 \\
(0.237)\end{array}$ & $\begin{array}{c}-0.0059084 \\
(0.011)^{* *}\end{array}$ & $\begin{array}{r}-0.0088575 \\
(0.006) * * *\end{array}$ & $\begin{array}{c}-0.005488 \\
(0.00)^{* * *}\end{array}$ \\
\hline ER & $\begin{array}{c}1.46356 \\
(0.001)^{* * *}\end{array}$ & $\begin{array}{l}1.299927 \\
(0.029)^{* *}\end{array}$ & $\begin{array}{c}4.513186 \\
(0.237)\end{array}$ & $\begin{array}{l}1.703939 \\
(0.012)^{* *}\end{array}$ & $\begin{array}{l}2.644256 \\
(0.002)^{* * *}\end{array}$ & $\begin{array}{l}1.723539 \\
(0.00)^{* * * *}\end{array}$ \\
\hline RAT & $\begin{array}{c}1.858852 \\
(0.195)\end{array}$ & $\begin{array}{l}13.58915 \\
(0.088)^{*}\end{array}$ & $\begin{array}{c}2.407338 \\
(0.569)\end{array}$ & $\begin{array}{l}12.55667 \\
(0.083)^{*}\end{array}$ & $\begin{array}{l}2.311221 \\
(0.045)^{* *}\end{array}$ & $\begin{array}{c}14.04712 \\
(0.001)^{* * * *}\end{array}$ \\
\hline N. obs. & 32 & 32 & 31 & 31 & 30 & 30 \\
\hline & 0.5892728 & 0.69595032 & 0.92214088 & 0.83907454 & 0.97201652 & 0.94143144 \\
\hline DWA & 0.2051 & & 0 & 0.1 & 0.0006 & 0.0862 \\
\hline AIC & & & & & 57.40244 & 57.49444 \\
\hline BIC & 88.09539 & 83.85708 & 76.86866 & 72.82145 & 76.54458 & 76.63658 \\
\hline
\end{tabular}

$* * *$ and $* * *$ : signifative at 10,5 and $1 \%$ respectively. 
